\title{
Reshaping relations between the state and the private sector post-COVID-19? Exploring the social licence framework
}

\author{
Emma Borg and Charlotte Unruh
}

\begin{abstract}
During the COVID-19 pandemic governments across the globe have provided unparalleled support to private sector firms. As a result, new oversight mechanisms are urgently needed, to enable society to assess and, if necessary, redress, moves by firms which have taken government aid. Many jurisdictions have seen the introduction of 'piecemeal' conditionality on different pots of aid. This paper argues that a better response would be to adopt a more unified approach. In particular, the paper explores the social licence framework as a potential way to 'build back better'. It is argued that the nature of the implicit social contract between society and the private sector provides the normative force underpinning demands for a social purpose for business, and that this purpose in turn can be used to specify the conditions firms must meet to legitimise their operations. The paper then considers three core elements involved in any introduction of a social licence framework, and surveys the potential benefits and challenges that might emerge in moving towards a social licence framework.
\end{abstract}

Keywords: Social licence, COVID-19, firms, conditionality, build back better, social contract, social purpose for business.

Note on the authors:

Emma Borg (ORCID ID: 0000-0003-2725-9568) is Professor of Philosophy at the University of Reading and Director of the Reading Centre for Cognition Research. She has published widely in philosophy of language, including two OUP monographs: Minimal Semantics (2004) and Pursuing Meaning (2012). Her work in business ethics includes: "The thesis of "doux commerce" and the social license to operate' (2020), Business Ethics: A European Review, and 'Epistemic virtues vs. ethical values in the financial services sector' (2017), co-author Brad Hooker, Journal of Business Ethics. She currently serves as an Independent Advisor to the Professional Standards Committee of Her Majesty's Revenue and Customs.

e.g.n.borg@reading.ac.uk

Charlotte Franziska Unruh (ORCID ID: 0000-0003-3953-7617) is currently a postdoctoral researcher in Ethics at the School of Governance at the Technical University of Munich; prior to that, she was research assistant on the 'Social Licence' project at the University of Reading. She has research interests in normative ethics and applied ethics.

charlotte.unruh@tum.de

(C) The author(s) 2021. This is an open access article licensed under a

Creative Commons Attribution-NonCommercial-NoDerivs 4.0 Unported License 
In an unprecedented reaction to the economic consequences of the coronavirus pandemic and lockdown measures, governments worldwide have released funds to support struggling businesses via stimulus packages, bailouts, or regulatory changes. ${ }^{1}$ In the UK, COVID-19 support for business has taken many forms, including loans, tax relief, cash grants, and the Coronavirus Job Retention Scheme, which at a peak in May 2020 saw government paying the wages of some 8.9 million workers (HM Revenue and Customs 2020). These economic support measures have required governments - and taxpayers - to take on large amounts of new debt. Thus in the UK the national debt exceeded $£ 2$ trillion in July 2020, with the Office for National Statistics noting that 'the government's support for individuals and businesses contributed to an increase of $34.2 \%$ in central government's day-to-day spending [in the five months between April and August 2020] compared with a year earlier' (Office for National Statistics 2020).

During the crisis, we have seen many examples of both commendable and problematic business behaviour. ${ }^{2}$ On the commendable side, for example, AstraZeneca committed to selling its vaccine at cost to developing countries, Bayer donated hydroxychloroquine for clinical trials, and Barbour repurposed production lines to make medical gowns. Supermarkets, including Sainsbury's and WM Morrison, swiftly provided help for vulnerable shoppers, L'Oréal decided to pay SME suppliers sooner than normal, and some companies, for example IKEA, returned COVID-19 aid. Unfortunately, however, there has also been problematic behaviour. For example, SportsDirect initially kept its stores open, categorising them as 'essential', and some workers raised concerns about the implementation of appropriate safety measures for warehouse and delivery staff at Amazon. ${ }^{3}$ A case that received particular attention was EasyJet, which distributed $£ 170$ million in dividends to shareholders while asking staff to take three months of unpaid leave in March 2020 (Leggett 2020). In April 2020, EasyJet accessed $£ 600$ million from the COVID Corporate Finance Facility, while in July it was reported that the company was using sickness records to determine up to 4,500 job cuts (Smoke 2020).

These divergent examples give rise to the question of what can, and should, be expected from firms which have taken COVID-19-related state aid. Trying to answer this question, we suggest, forces us to consider the fundamental issue of the purpose of the private sector and its relationship with society at large. To see this, we begin by outlining three options for the conditions which could be placed on COVID-19 relief measures: first, that no conditions should be imposed on receipt of this support.

\footnotetext{
${ }^{1}$ For a review of government support for European companies, see Geoffrey et al. (2020).

${ }^{2}$ For a non-exhaustive, but illustrative list of corporate behaviour in the COVID-19 crisis, see Tett (2020).

${ }^{3}$ See, e.g., https://www.wired.com/story/amazon-workers-pandemic-risks-own-words/
} 
Second, that standard, existing conditions are sufficient. Third, that a new kind of condition is needed. We argue that this third option is to be preferred and then proceed to explore one possible option for a new approach to conditionality: the so-called 'social licence' framework. ${ }^{4}$ In the section on 'The social licence framework and precedents for purpose' we introduce the social licence model, situating it with respect to recent moves to recognise a social purpose for business. We argue that talk of business purpose alone cannot be properly substantiated without appeal to the nature of the implicit social contract between society and the private sector, since it is this grounding which provides the normative force for appeals to social purpose for business. $^{5}$ In 'The social licence framework and standard regulation' we attempt to further flesh out the model by comparing and contrasting it to standard regulation. These sections attempt the theoretical work needed to provide at least an initial understanding of the social licence model. Then in 'The social licence in practice' we explore three more concrete elements which we take it would need to be involved in any introduction of a social licence framework (concerning mandatory reporting, introduction of social licence boards, and creation/adaptation of monitoring bodies). Finally, we conclude by surveying the potential benefits and challenges that might emerge in moving towards a social licence framework.

\footnotetext{
${ }^{4}$ The concept of the social licence to operate has its roots in the mining and extraction fields and it has been subject to some extended investigation (e.g., Morrison 2014). However, we suggest that further work is needed if the concept is to provide a genuine policy alternative to standard conditions placed on COVID-19 relief measures. The current paper is thus an attempt to set out the theoretical underpinnings of the framework and to provide an initial outline of some of the core issues involved were the framework to be conceived of as a form of regulatory device (note not all advocates of the social licence approach conceive of it in this way; for an excellent discussion of an alternative conception, focusing on financial markets, see Rouch 2020).

${ }^{5}$ There is an important caveat to note here, concerning the notion of a social contract. In philosophy, the idea of a social contract is most clearly associated with Hobbes, Locke, Rousseau, and Rawls, where the focus is on the relationship between individual citizens (rather than organisations such as businesses) and the state, and the conditions that those individuals tacitly agree to in order to acquire the benefits of social organisation. However, other philosophers which we can characterise as broadly 'contractarian' place less emphasis on an implicit contract, instead appealing to demands that it is reasonable to impose on parties. So, for instance, Scanlon holds that what underlies claims concerning what we owe to one another is a concern to act in ways that could be justified to those affected on grounds that they could not reasonably reject; see Scanlon (1998). While we lean towards a more Scanlonian understanding of the issues here, we will continue to talk in terms of the 'social contract' in what follows, as this terminology captures much of what we want to say and has the benefit of wider common currency.
} 


\section{Three options for imposing conditions on receipt of COVID-19-related support for business}

During the pandemic, governments across the globe have stepped in as buyer and lender of last resort for private sector firms. This support has been both welcome and necessary; without it there can be no question that we would have seen far higher rates of business insolvency, correlated with much higher levels of redundancy and unemployment, and an inability to restart economic activity post-pandemic. However, this reshaping of the relationship between state and private sector should lead us to ask questions about the conditions placed on receipt of support. Crudely put, what should the state expect to get for its money, and should it put any conditions on accessing the funds to ensure these expectations are met? Below, we sketch three possible answers to these questions.

\section{No conditions}

There are undoubtedly goods which result from saving private sector firms and propping up the economy per se. An example is the preservation of jobs, with increased income for individuals, less cost to the state in unemployment support, and the maintaining of a skilled workforce, not to mention the benefits to those who are directly or indirectly economically dependent on the employees involved. Support for struggling businesses now will also help to preserve future tax revenue from companies and might be thought to enhance a country's reputation as an attractive location for businesses and future investors (by displaying the government's 'pro-business' mindset). For these reasons, then, ensuring the survival of private sector firms at this time of crisis and enabling a swift return to business as usual might be thought to be the full and final aim of support packages.

Furthermore, there might be a concern that the imposition of conditions on COVID-19-related relief could undermine recovery. For instance, the imposition of conditions might disincentivise uptake of the support, preventing workers from benefitting (this worry was articulated by both Justin Trudeau and the UK Treasury). ${ }^{6}$ Or again, there might be a worry that conditions might delay delivery of state support.

\footnotetext{
${ }^{6}$ See Taxwatch (n.d.). See also Berry et al. (2020): 'Going further, companies beyond a certain level of profitability could be required to supplement the state's contribution and top up staff pay to 100 per cent. Of course, the danger with this approach is that it could disincentivise companies from taking up the furlough scheme in the first place, unintentionally hurting the workers it is designed to help. Trade unions are at present concerned that not enough workers are being furloughed, and unemployment continues to rise-so extreme caution would be needed in pursuing any measures that risked exacerbating this problem.'
} 
In the context of EU state aid, this concern has been raised by the European Trade Union Confederation (ETUC) in a letter to state leaders, asking them 'NOT to introduce veto rights and budgetary conditionalities on National Recovery Plans, which would harm the potential of the proposed recovery strategy to prevent a massive economic and employment crisis in the EU' (ETUC 2020). These ideas - that the sole aim of funds is to ensure the survival of viable businesses and that imposing conditions on accessing funds would impede survival-may lead to the conclusion that no conditions should be placed on firms accessing COVID-19-related support (besides the requirement that firms use the resources in the best way possible to guarantee their survival post-crisis).

However, there is a strong case to be made that COVID-19 state aid should aim at more than just promoting a swift return to business as usual. Pre-crisis, relations between the state and the private sector were far from ideal. Both large institutions and indeed whole sectors have been hit by scandals apparently demonstrating not merely individual bad behaviour but a systematic mis-alignment between business behaviour and the public good (consider questions about the relationship between Boeing and the Federal Aviation Administration or the alleged mis-selling of powerful opioid painkillers by Purdue, the unauthorised harvesting and selling of personal data by a range of companies, and the behaviour of the big banks and other financial institutions during the crash of 2008). Furthermore, society is currently facing a range of extreme challenges (of which climate change is clearly the most profound, but note also aging populations, social inequality, growth of AI, etc). A return to pre-crisis relations would not address any of these issues. Instead, then, it seems that the support offered by governments to business provides a window of opportunity for the state reasonably to ask more of business. ${ }^{7}$ But what more?

\section{Standard regulation}

Although at the start of the pandemic sources of support were developed which placed very few conditions on access, across the globe governments were relatively quick to reject the 'no conditions' position and move to some stricter form of conditionality. So, for instance, in the UK, the COVID Corporate Financing Facility (CCFF) was launched by Chancellor Rishi Sunak on 17 March 2020 to offer financing

\footnotetext{
${ }^{7}$ As Christiana Figueres (former executive secretary of the UN Framework Convention on Climate Change) noted recently (Bloomberg New Economy Forum panel, 19 November 2020), governments worldwide are planning on injecting \$12 trillion into economies over the next 18 months in a response to the financial impacts of COVID-19. That scale of stimulus is unrepeatable in the next decade so, if it is to be of most value to the future generations that will have to pay it off, it must address all of the crises that the world is currently facing.
} 
to larger firms. ${ }^{8}$ However, it was not until 19 May that the Bank of England announced that any company wishing to draw from the CCFF with a term going beyond 21 May 2021 needed to sign a letter committing to restraint regarding senior pay and paying dividends. This commitment was not imposed retrospectively on those firms which had accessed funds before May. The precise conditions placed on accessing support have differed across jurisdictions and across different sources of support. For instance, in France, the government attached environmental conditions to the Air France bailout, while in Denmark, companies based in tax havens were restricted from accessing support. Despite this variation, however, we will introduce a general term — 'standard regulation'-to cover all extant conditions in the current patchwork of different rules and requirements relating to COVID-19 business relief.

In this section, we argue that standard regulation faces significant problems. While some of these problems (those we below label 'contingent') might initially seem as if they can be overcome by regulation that is better designed and executed, we argue that, in many cases, the problems really emerge from issues which are inherent to standard regulation itself (these are the 'inherent' problems discussed below). If this is right, it shows that there is a need to explore other models for reshaping the relationship between the state and the private sector. (Note the focus of discussion in the next section is on standard regulation in the specific context of COVID-19 business relief. $)^{9}$

\section{Contingent problems for standard regulation}

Standard, extant conditions might be thought problematic for a range of potentially contingent reasons, i.e. worries that, it seems, might be avoided given better drafting of the conditions or more careful enforcement.

To begin with, extant regulations lack transparency and accountability mechanisms. For example, in a report in July 2020, Positive Money notes 'considerable transparency gaps' (Barmer et al. 2020: 14) in the COVID Corporate Financing Facility. Transparency International, together with the Fraud Advisory Panel, and Spotlight Corruption, wrote a letter to the UK chancellor protesting the lack of transparency over who is receiving COVID-19-related loans, ${ }^{10}$ arguing that the 'UK Government

\footnotetext{
${ }^{8}$ As of 19 August 2020, the facility had supported 65 businesses, purchasing $£ 17.53$ billion of short-term debt in the form of commercial paper (less redemptions) (Hutton \& Keep 2020).

${ }^{9} \mathrm{We}$ believe that similar problems arise for standard regulation in other contexts. For example, measures adopted after the 2008 financial crisis arguably largely followed standard regulation and suffered from problems similar to those we identify here (see Borg 2020: 7-9). However, unfortunately we do not have the space to explore these wider issues here.

${ }^{10}$ The letter is available for download here: https://www.transparency.org.uk/publications/letter-to-thechancellor-request-to-publish-names-of-all-companies-receiving-bbls-and-cbils-to-prevent-fraud
} 
has ... resisted greater transparency on the [other] recipients of COVID-related loans, including the $£ 17$ billion provided via the Coronavirus Large Business Interruption Loan Scheme (CLBILS) through the British Business Bank' (Donaldson 2020). In addition, extant regulations often fail to support commitments to a fair and green recovery. The CCFF in the UK is an example: money was made available with no environmental strings attached. Similarly, the EU's COVID-19 recovery fund 'Next Generation EU' has been criticised for not containing ambitious enough climate goals (Climate Action Network Europe 2020: 2). Concerns about a lack of conditions to ensure fairness have also been raised. For instance, aside from being big polluters, airlines receiving money through the CCFF scheme have been criticised for issues such as misusing the job retention scheme (British Airways) or minimising tax (Wizzair) (Smoke 2020).

Another worry is that standard regulations do not address intergenerational justice concerns. We owe future generations a sustainable and ethical private sector, especially given that future taxpayers will foot the bill for today's support measures. One way to address intergenerational justice concerns would be by ensuring that funding is used to build a more sustainable and resilient economy, and to ensure that older generations bear a fair share of future tax rises and reforms (Corfe 2020). ${ }^{11}$ However, present regulations are not always sensitive to such principles and some schemes conflict with the interests of future generations, for example due to the lack of environmental protections (Climate Action Network Europe 2020). Finally, patchwork regulations lead to different standards and uncertainty. As noted already, current regulations differ across jurisdictions and support schemes, making it harder for firms to be sure that they are complying with all the requirements. More unified regulation would be desirable to create a level playing field, but also to make it easier for companies operating in different countries to ensure that they comply with requirements. ${ }^{12}$

\section{Inherent problems for standard regulation}

It is tempting to think that all of the above worries are merely contingent and could be assuaged by better drafting and more sensitivity to a wider range of aims. However, we contend that many of these apparently contingent worries actually stem from the

\footnotetext{
${ }^{11}$ See also Filipova et al. (2020): "the current crisis risks overshadowing these concerns and tilting decision-making even more either towards the very short-term or towards the interest of only some age groups'.

${ }^{12}$ See also British Institute of International and Comparative Law, Civic Consulting, DirectorateGeneral for Justice and Consumers (European Commission) \& LSE (2020: 17): 'The majority of stakeholders indicated that mandatory due diligence as a legal standard of care ... may provide potential benefits to business relating to harmonization, legal certainty, a level playing field, and increasing leverage in their business relationships throughout the supply chain through a non-negotiable standard.'
} 
essential nature of standard regulation itself. If right, this means that standard regulation is in fact ill suited to provide the kind of long-term, systemic change in business behaviour that we need. So, for instance, we think that the following drawbacks are inherent in standard regulation and give rise to many of the problems enumerated above.

An inherent problem for standard regulation is that it is short-sighted. Today's support schemes are funded with the money of future taxpayers. But conditions attached to government funding are temporary. They are not well suited to reshape the private sector in the long run, ${ }^{13}$ or to alleviate intergenerational justice concerns as described above. For this purpose, measures that are designed to take effect and be enforced beyond short-term time horizons are necessary. Moreover, conditions attached to support schemes only apply to companies that participate in these schemes. Environmental conditions might be futile if competitors are not subject to the same conditions. ${ }^{14}$ Finally, even if the playing field is level, businesses might try to find ways around regulations, or follow the letter of the rules without embracing a general ethical attitude ('hitting the target but missing the point'); see, for example, the discussion of EasyJet at the start of this paper. It is clear that standard regulations do not inspire best practice.

Relatedly, standard regulation does not change the conversation. Extant conditions only set a minimum standard. They do not provide a positive vision, encourage social dialogue, or strengthen the voices of workers and communities. In fact, current support schemes could exacerbate the power of shareholders over workers. ${ }^{15}$ For a truly fair and green recovery, it seems a more powerful narrative is needed.

Finally, standard regulation is complex and inflexible. There is an inherent tension between allowing flexibility for firms by creating exceptions and sector-specific rules and reducing complexity of the rules. When regulations are too complex, they can become difficult to navigate ${ }^{16}$ and possibly delay delivery of government funding. On the flipside, even complex regulation cannot take into account every firm's individual circumstances, leading to binary rulings in areas where more nuanced decision-making is needed.

\footnotetext{
${ }^{13}$ In recognition of this point, Shadow Climate Change Minister Matthew Pennycook has suggested going much further than a Social Licence model and part-nationalising some firms in the aviation sector which receive state support: 'Take an equity stake so you can drive and change behaviour over the long run, conditionality in this moment isn't going to be enough' (Gye 2020).

${ }^{14}$ For example, in the case of environmental conditions for airlines, a worry is that competitors that are not subject to conditions will just fill in (Costanzo 2020).

${ }^{15}$ Positive Money claims that the current corporate model maintains unequal power structures between shareholders and workers, and the response to the current crisis exacerbates such inequalities (Barmer et al. 2020).

${ }^{16}$ For example, many businesses in Russia have not applied for the government's financial support fund because of complex rules (Ashby 2020).
} 
If these objections are valid, they point to a need to explore new models for reshaping the relationship between the state and the private sector-conditions on accessing state support that do not rely (solely) on standard regulation. ${ }^{17}$ The rest of this paper is devoted to exploring one such model: the social licence for business framework. In the next section, we introduce the notion of the social licence by situating it with respect to recent moves discussing the need for a social purpose for businesses. Then, in 'The social licence framework and standard regulation', we return to the challenges to standard regulation explored in this section, asking whether conditions emerging through the social licence framework might be able to ameliorate or avoid these challenges.

\section{The social licence framework and precedents for purpose}

The social licence framework views business and the state as partners in a social contract, with the unifying aim of creating social value alongside profit generation. ${ }^{18}$ Building on the social contract tradition in philosophy, Borg (2020) argues that firms enjoy a range of benefits from participating in society and have obligations to reciprocate these benefits. This is because 'given the benefits they enjoy, banks (and other business organisations) could not reasonably reject a principle that requires them to contribute to social goods' (5). Society, then, is entitled to demand that businesses

\footnotetext{
${ }^{17}$ The ideas that the role of business is negotiable and must be responsive to changing needs and circumstances in society, and that a narrative is needed for legitimacy of business, might be thought to be anticipated by Scanlon when he writes (2003, Ch. 3: 50-1): 'an important social institution enabling some to wield significant power over others is unlikely to exist without some public rationale - at the very least an account put forth for public consumption of why this institution is legitimate and rational. This will include some conception of the social goals the institution is taken to serve and of the way in which the authority exercised by participants in the institution is rationally related to those goals. If the institution is not merely rationalized by those wishing to maintain its power, but in fact generally accepted as legitimate then some conception of this sort will be fairly generally accepted in the society and rendered coherent with other aspects of the prevailing views. ... But while the limits of debate are in this sense set by prevailing views, the fact that the dominant conception of an institution is not taken at face value but must be shown to be coherent and consistent with other social values provides a measure of independence and allows for criticism through which the prevailing conception of an institution can be extended, clarified, and altered.'

${ }^{18}$ This running together of the notions of 'social contract' and 'social licence to operate' can also be seen in John Kay's excellent essay 'The concept of the corporation', where he writes (2019: 1139): 'The licence to operate is not, as sometimes suggested, a fee for the privilege of limited liability, but rather an understanding which arises from the knowledge that all property rights in a complex economy are social constructions, and regulation of such social construction is necessary to legitimate the private exercise of authority - as reflected in the considerable power held by executives of large corporations. Actions such as aggressive tax avoidance represent a breach of this implicit contract with society.'
} 
operate in line with their social purpose, and to put structures in place that ensure compliance. The framework thus stresses, on the one hand, the normative force of the requirement for firms to have a social purpose and, on the other, takes this social purpose to generate a set of terms which a firm must meet in order to be granted, or to maintain, its social licence to operate.

Since the terms of a social licence (as conceived of here) are parasitic on a firm's social purpose, more needs to be said about this core notion of purpose. While not universally acknowledged, the idea that firms need to have a social purpose has become more influential over recent years, both with firms and regulators, and with academics and commentators. ${ }^{19}$ From the perspective of academic engagement, the major British Academy research programme on 'The Future of the Corporation' (led by Colin Mayer) has extensively researched the role and nature of corporate purpose, setting out principles for reform of business. ${ }^{20}$ The reforms replace shareholder interests with corporate purpose, demanding that 'Corporate law should place purpose at the heart of the corporation and require directors to state their purposes and demonstrate commitment to them. ... Corporate governance should ... determine a set of values necessary to deliver purpose, embedded in their company culture. ... Performance should be measured against fulfilment of corporate purposes' (British Academy 2019; see also Mayer 2020).

Recently, the project has provided an appealing summary definition of the purpose of business as 'profitably solving the problems of people and planet, and not profiting from creating problems'. While this seems right as an overarching statement, we suggest that the social licence framework may in addition require a more nuanced understanding of social purpose, according to which every company specifies its social purpose individually. Companies should have statements of social purpose, which specify the way in which an individual company sees its social contribution. Such statements would be set (not by directors alone but) through collaborative dialogue between senior management, shareholders, workers, and wider stakeholders

\footnotetext{
${ }^{19}$ Indeed, in recent debates in this area talk of 'purpose' has largely replaced the talk of 'culture' which ensued after the financial crisis. While we think that the notion of purpose is an advance on culture (as it is more tangible and easier to assess/measure against), we note that ultimately it may turn out not be the answer here. As noted in footnote 3, pursuit of a more Scanlonian approach could perhaps avoid appealing both to the social contract and to the idea of a social purpose for business. Instead, the operative notion would be the requirement that companies act on policies that can be justified to those affected on grounds those affected could not reasonably reject. We are grateful to Philip Stratton-Lake for stressing this point.

${ }^{20}$ See also Dirk Schoenmaker \& Willem Schramade (2019), who have argued that we should replace Friedman-esque conceptions of business purpose with a model that fully integrates financial, social, and ecological concerns (for a call for a new paradigm for the financial system along similar lines, see Loorbach et al. 2020: 60).
} 
(we return to this question of who sets a firm's individualised social purpose below). The social licence for any given firm, then, would capture the specific terms which emerge from this individualised statement of the organisation's social purpose. This might contain elements common to all social licences (for instance, a requirement to make appropriate tax contributions rather than engaging in highly aggressive tax avoidance might be a common feature) but would be tailored to the specific size, nature, and function of an organisation (for instance, a big $\mathrm{CO}_{2}$ emitter might have ambitious carbon reduction targets written into its social licence, while a new start-up that had already minimised its $\mathrm{CO}_{2}$ profile might just have $\mathrm{CO}_{2}$ maintenance written into its current licence).

Alongside academic exploration, the business world itself has also seen much greater discussion of the wider social purpose of business in recent years. For instance, the US Business Roundtable released a 'Statement on the Purpose of a Corporation' in 2019 (signed by 181 CEOs of major US corporations, that together have a market capitalisation exceeding \$13 trillion) which emphasises stakeholders' benefits. ${ }^{21}$ Klaus Schwab, Founder and Executive Chairman of the World Economic Forum, describes as 'stakeholder capitalism' a model that 'positions private corporations as trustees of society, and is clearly the best response to today's social and environmental challenges.' Schwab argues that, to begin with, 'a new measure of "shared value creation" should include "environmental, social, and governance" (ESG) goals as a complement to standard financial metrics' (Schwab 2019). Another notable initiative is the European Commission's corporate sustainability initiative, ${ }^{22}$ which would enable companies to focus on long-term sustainable value creation rather than short-term benefits. While French legislation on due diligence requires that companies establish a vigilance plan, publish the plan, implement the plan, and publish annual implementation reports. ${ }^{23}$

In the UK, a new Corporate Governance Code and a new Guidance on Board Effectiveness were enacted in July 2018 with emphasis on the long-term sustainability of companies. The Code includes the provision that 'The board should assess the basis on which the company generates and preserves value over the long-term. It should describe in the annual report how opportunities and risks to the future success of the business have been considered and addressed, the sustainability of the company's business model and how its governance contributes to the delivery of its strategy'

\footnotetext{
${ }^{21}$ Value of market capitalisation taken from Bebchuk \& Tallarita (2020: 12-13).

${ }^{22} \mathrm{~A}$ description of this initiative is available under https://ec.europa.eu/info/law/better-regulation/haveyour-say/initiatives/12548-Sustainable-corporate-governance

${ }^{23}$ More information on the French due diligence law can be found on the Business \& Human Rights Resource Centre website https://www.business-humanrights.org/en/latest-news/france-natl-assemblyadopts-law-imposing-due-diligence-on-multinationals-to-prevent-serious-human-rights-abuses-in-supplychains/.
} 
(UK Corporate Governance Code 2018). Finally, in November 2019, the UK Institute of Directors launched a Manifesto on Corporate Governance, which called for the adoption of business purpose clauses, a public service corporation (a newly defined corporate form to deliver outsourcing of public services), a code of business conduct, mandatory training for directors, and a corporate governance commission (Institute of Directors 2019).

Construing business purpose as something other than increasing shareholder value, then, definitely seems like an idea whose time has come. But why should we tie business purpose to talk of social contracts, in the way that (our conception of) the social licence model does? The answer is that making explicit the role of business as partners in a social contract provides much more than just a rhetorical device. Instead, it establishes the normative force of moves to codify and regulate the social purpose of business: because businesses benefit from societal support (transparently at the current time in terms of COVID-19 relief, but less overtly at all times, through things like the provision of legal protections, well-educated workers, transport infrastructure, etc) society has the right to demand that businesses contribute to the long-term good of society.

This means that firms must act to bring about social value in the course of pursuing legitimate, profit-making activities. To fulfil the terms of their social licence, companies need to show that they take the interests of stakeholders into account when making decisions about activities, acting in ways that can be justified to those affected on grounds they could not reasonably reject. They also need to cultivate awareness of, and take responsibility for, the long-term consequences of their activities. ${ }^{24}$ In this way, it seems that a social licence framework might be able to provide more than just window-dressing because:

- It makes visible the need for reform: business has failed in the past to meet obligations that society can reasonably expect it to meet.

- It emphasises the responsibility of business to pay back: the bargain struck for getting state relief is that businesses go on to create social value; no society should support firms whose activities undermine the long-term welfare of that society.

- It provides a positive vision: Too often, regulations are just tick-box exercises setting minimum standards for business. They aim to ensure that business practices do not clash with written legislation, rather than aiming for positive value.

\footnotetext{
${ }^{24}$ This is discussed further in our consultation document 'Social licence for business A framework for reshaping the private sector in a post-pandemic world', available at https://research.reading.ac.uk/sociallicence-for-business/wp-content/uploads/sites/171/Unorganized/B26658-Social-licence-WEB-LONGREF_Final.pdf
} 
What is needed is a shift in mindset in business. The social licence framework provides a positive narrative. ${ }^{25}$

- It restores warranted trust in business: If the private sector is perceived as a partner in the social contract, practices to ensure social value creation are widely practised, and business is being held accountable, this will restore lost trust in business. $^{26}$

On this conception, the social licence model provides a way to reframe and reshape the debate about what the private sector owes to society, as well as providing a framework for the articulation and measurement of better business behaviour. In this latter respect, the social licence brings together performance against a broad range of targets (including such varied moves as better reporting of progress against environmental and social targets, moves to strengthen the worker's voice in company decision-making, investment in staff training and support, and community outreach), whilst allowing firms to tell a narrative about the steps they are taking. The framework allows a firm to set out what matters most to it as an organisation and how it is seeking to improve performance against relevant targets.

Like standard regulation, then, the social licence model will require mechanisms for codifying, measuring and enforcing standards, but, unlike standard regulation, companies will have some flexibility on prioritising ethical metrics and deciding on implementation methods. This leads us back to our earlier question concerning the problems faced by attempts to use standard regulation to set and enforce more ethical behaviour. In the next section, then, we explore whether the kind of conditionality that emerges from the social licence framework can address the challenges levelled at standard regulation.

\section{The social licence framework and standard regulation}

It should be clear at the start that the social licence model cannot replace standard regulation when it comes to setting clear legal boundaries for permissible business behaviour. Social dialogue, while important and urgently needed, does not provide democratic legitimacy. Corporate misbehaviour needs to be liable to legal prohibition and sanctions. Reforms motivated by the social licence model are thus best thought of

\footnotetext{
${ }^{25}$ As such, the social licence should not generally contain only commitments not to do harm, but should explicitly include considerations as to what the positive social contributions of the firm are. In ethics, duties not to harm are often seen as stronger than duties of beneficence. Our point here is that, in principle, business has both kinds of duties to society. We are grateful to a reviewer for stressing this point.

${ }^{26}$ For the difference between warranted and unwarranted trust, see O’Neill (2014).
} 
complementary to standard regulation. As noted above, however, standard regulation alone seems ill suited to improving ethical behaviour. An important question, then, is whether the kind of conditionality emerging from a social licence framework would be any better suited to this task?

The first inherent worry that we looked at with standard conditions was that they are short-sighted and temporary: although COVID-19 business relief uses the money of future taxpayers, conditions imposed on accessing those funds will expire (as loans are repaid or the use of the funds ceases). Setting a social licence for a firm, on the other hand, and specifying what actions will be needed to meet the terms of such a licence, has an inherently long-term perspective. Instigating this sort of change would also not be time-limited. Reshaping the relationship between the state and the private sector in order to clarify and codify what business owes to society makes clear that the two are in an ongoing partnership, with the private sector required to calibrate its aims and actions to take account of social goods in perpetuity, as it were. Secondly, in contrast to standard regulation, the social licence is evidently aspirational (rather than being concerned with setting minimum standards). Generating a statement of a firm's social purpose and how that purpose will be achieved provides an opportunity for an organisation to engage with a wide group of stakeholders, constructing a narrative about what it does and what it wants to be, in a way that can inspire best practice amongst employees and support and encourage brand loyalty. This narrative approach also creates an opportunity for a degree of flexibility not found with standard regulation.

Furthermore, since the social licence framework aims at changing the mindset around business practices (ensuring all recognise that company value goes far beyond quarterly reporting), it should help to reduce the game-playing to which standard regulation is vulnerable. If implemented properly, a social licence model should undercut an organisation's motivation to exploit loopholes or to utilise its resources in trying to game the system. By increasing the social pressure on firms to do the right thing (in part, by making it more transparent when they do not), the social licence model might also ameliorate at least some concerns about 'green washing' and surface-deep changes. Unlike standard regulation, then, the social licence model does change the conversation. It seeks to reset state/private sector relations by clarifying the social contract in place and showing how this gives rise to a requirement that firms contribute to the public good. It thus re-establishes a perspective of partnership which (arguably) was in existence at the birth of the limited liability corporation itself (see Norman 2011). Furthermore, it seems clear that, if we are to carry all parties along with the need for change in business, we must get the language of change right. By making clear what society owes to businesses, and what businesses in turn owe to society, and by focusing attention on what we all owe to future citizens of the world, the social licence framework might succeed in creating a genuine partnership for change. 
Finally, a social licence framework might also be able to avoid some unhelpful complexity around trying to legislate for ethical behaviour. For, rather than trying to regulate against every specific form of action that runs counter to the social good, a social licence framework would instead seek agreement on the principles that lie behind piecemeal conditions. To see this, consider the above example of the CCFF: initially the UK government imposed no conditions on access to these funds, only later requiring firms to show restraint in paying dividends and senior pay awards. However, in a context in which a social licence framework was operative, no such explicit additional conditions should be required. A firm which had undertaken to act in line with its social purpose would already be committed to avoiding the use of taxpayer-funded schemes for the short-term benefit of the firm, over the good of wider society. In this way, a social licence framework might generalise over a range of inappropriate actions.

It is clear, however, that this raises substantive questions about how firms are supposed to know what they are committed to, and how these commitments are enforced. This brings us to the most challenging aspect of the social licence framework, for the model seeks a form of enforcement which is not dependent (only) on black and white rules, but which is instead able to make contextualised value judgements, ones which are sensitive to a wide range of (potentially competing) factors. Yet a system which allows for this kind of decision-making runs a serious risk of appearing arbitrary and subjective, failing to create the level playing field that is needed. Furthermore, such a model may fail to give firms the confidence that they need in order to make informed judgements about what to do and how to behave in order avoid contravention. In this respect, it is important to note that the social licence model does not obviate the need for monitoring, measuring, and enforcing of standards. Where a firm fails to set an adequate social purpose, does not set it in an adequate way (for example, fails to engage in dialogue with a significant group of stakeholders) or fails to report on or to take the steps necessary to fulfil its purpose, there will need to be mechanisms capable of uncovering this and taking action. As such, there are thus clear points of continuity between the social licence model and standard regulation. However, the social licence framework would also necessitate new mechanisms and methods of redress. After all, rather than black and white rulings about whether a firm has met or contravened a piece of standard regulation, testing for compliance with the social licence framework would require a more nuanced account of whether a firm's self-imposed social purpose was acceptable (for example, ambitious enough) and whether the steps taken to meet it were adequate. This would involve the need for new bodies for adjudicating on conflicts, for example between firms and stakeholders. Yet, given the partnership perspective essential to the framework, initially at least dispute resolution would be addressed through dialogue, 
mediation, and mutual understanding, with firms, stakeholders, and monitoring bodies attempting to come to a shared agreement about what actions a firm needs to undertake. While it is beyond the scope of this article to consider in detail what such implementation might look like, we present some thoughts in the next section.

\section{The social licence in practice}

While the above discussion suggests that the social licence model might provide a useful normative theoretical concept, moving beyond this into the realm of concrete application would clearly require extensive further work. However, it seems that this kind of work will be required (whatever framework is ultimately adopted) since there are good reasons to think that affecting change cannot be left to market forces alone. We are, as Lord Victor Adebowale (CBE, Chair of Social Enterprise UK) put it at the British Academy Future of the Corporation's Purpose Summit, currently standing on a burning platform. ${ }^{27}$ Change is needed at a pace which is likely to outstrip that of self-regulated change within the business world. Furthermore, while many in business appreciate the need for change, not all do (see, for example, the Council of Institutional Investor's response to the US Business Roundtable ${ }^{28}$ ). and even where there are public commitments to better business behaviour, concerns about the extent to which these commitments will actually lead to change remain. ${ }^{29}$ If change is not mandated, those firms which persevere with 'business as usual', failing to make green and social reforms that go beyond mere 'green washing', may put other firms at a competitive disadvantage. A lack of regulation around reporting will also undermine the power of consumer activism, with firms making insufficient or inappropriate information available to consumers. To create and maintain a level playing field for the firms that are

\footnotetext{
${ }^{27}$ The Purpose Summit took place on 1-4 February 2021. More information is available on the website of the Future of the Corporation project: https://www.thebritishacademy.ac.uk/programmes/future-ofthe-corporation/events/purpose-summit/

${ }^{28}$ Available at https://www.cii.org/aug19_brt_response

${ }^{29}$ For instance, Bebchuk \& Tallarita (2020) explore 'the expected effects of the widely-celebrated [US Business Roundtable] statement', arguing that 'the statement is largely a rhetorical public relations move rather than the harbinger of meaningful change'. In line with our argument here, Bebchuk \& Tallarita 'take stakeholder interests seriously and believe that some of the adverse effects that companies impose on stakeholders raise serious policy concerns and warrant legal and regulatory intervention' (6). Interestingly, they argue that 'the acceptance of stakeholderism [the view that corporate directors should consider the well-being of all stakeholders] would have broad detrimental effects' (65), for example by reducing accountability to shareholders and delaying necessary reforms that would benefit stakeholders. See their blog piece at https://corpgov.law.harvard.edu/2020/03/02/the-illusory-promise-ofstakeholder-governance/
} 
trying to do things better, then, it seems governments must step in. ${ }^{30}$ Yet, if our earlier discussion concerning the inadequacy of standard regulation in the realm of ethical behaviour is right, then some new form of regulatory mechanism is needed. Whether framed in terms of the social licence framework or not, questions of standard setting and enforcement which allow for nuance, aspiration, and intentions cannot be avoided. Thus in this section, we look at three specific elements that we take it would need to be involved in any moves towards implementing the kind of non-standard conditionality envisaged by the social licence model.

\section{Mandatory implementation of a social licence strategy}

The first measure is the mandatory implementation of a social licence strategy. Companies would be required to implement a social licence strategy and disclose key environmental, ${ }^{31}$ social, ${ }^{32}$ and governance risks. ${ }^{33}$ Such strategies would look different for different businesses, they are not 'one size fits all'. ${ }^{34}$ In particular, the size and activities of a firm will likely influence the strategy. However, the general idea is that such a strategy would reflect a move away from corporate governance models based on shareholder primacy. ${ }^{35}$

Such a social licence strategy could be modelled on a suggestion for a corporate sustainability strategy, as outlined in the statement Corporate Governance for Sustainability. The seventy-six academic signatories of the statement recommend that:

In order to: counteract the pressures imposed on directors by financial markets to maximise short-term shareholder value; increase director accountability; and ensure a proper consideration of corporate long-term interests and sustainability risks, we recommend that:

\footnotetext{
${ }^{30}$ As Leo Strine, former chief justice of the Supreme Court of Delaware, writes (2015: 8-9): 'Declaring that directors may consider other interests [than shareholder interests] without giving those interests voting or enforcement rights, or any real leverage to influence decision-making, is more an exercise in feeling good than in doing good. In fact, it largely shifts power to the directors to couch their own actions in whatever guise they find convenient, without making them more accountable to any interest.'

${ }^{31}$ For a call for green economic renewal, see Institute for Innovation and Public Purpose (2020).

${ }^{32}$ For a call for better standards of tax compliance post COVID-19, see Taxwatch (n.d.).

${ }^{33}$ For a call for a corporate sustainability strategy, see Johnston et al. (2020).

${ }^{34}$ For the blog of the New Economics Foundation, Chapman (2020) suggests different frameworks for bailout conditions, depending on size of business and business area.

${ }^{35}$ See also Kavanagh \& Veldman (2020). Another voice for a move away from shareholder primacy in UK corporate governance is the Trades Union Congress (2020). See also the OECD (2020: 17): 'Calls are already being heard to ensure that fiscal support will create value not only for company shareholders, but also for company stakeholders and the public more broadly.'
} 
a. directors should be subject to a legally-binding obligation to develop, disclose and implement, on behalf of the company, a forward-looking corporate sustainability strategy ...

b. whilst directors should have discretion as regards identifying which issues are material for the corporate sustainability strategy, the law should clarify that the purpose of requiring companies to produce such a strategy is to ensure respect for the planetary boundaries and human rights, as well as integration of ESG considerations into all aspects of the company's operations. ...

c. a specified percentage of the KPIs and remuneration of executive management should be linked to the achievement of measurable targets set in the company's sustainability strategy ... (Johnston et al. 2020).

Similarly, the social licence would require firms to develop a forward-looking social licence strategy, which should be specific to the company purpose and specific activities and relations to stakeholders, but also address general ESG issues across company operations and the supply chain. It would identify risks and problem areas, while developing a forward-looking strategy with measurable targets. Importantly, this requirement is not satisfied by a Corporate Social Responsibility agenda and targets that are purely about philanthropy or health and safety. The strategy should seriously consider the social impacts of every activity within the company.

\section{Social licence boards}

As stressed above, the terms of a social licence would need to be determined in a collaborative and ongoing dialogue with governments, employees, further stakeholders, and the broader public. ${ }^{36}$ Multinational companies could be required to install an additional board that operates alongside the corporate board, to formulate social licence terms and hold the executive to account for meeting these terms. ${ }^{37}$ This social licence board would broaden the voices being heard.

The signatories of the statement cited above moreover suggest that 'a non-executive committee, composed of independent experts and chaired by a designated nonexecutive director, should be set up and tasked with monitoring and reviewing the

\footnotetext{
${ }^{36}$ The International Labour Organization (2020) presents social dialogue as one of four pillars to fight COVID-19. From a perspective on ESG investing, Indranil Ghosh and Shelly Goldberg note that system change 'will require a partnership between investors, businesses, and governments' (Ghosh \& Goldberg 2020).

${ }^{37}$ Worker representation on company boards is proposed, for example, by the High Pay Centre (2020) as a condition for government bailouts of large businesses: 'Government bail-outs of large businesses affected by the coronavirus must include social and environmental conditions including fair pay, fair tax contributions and worker representation on company boards.'
} 
content and implementation of the sustainability strategy' to ensure directors' accountability.

While establishing such committees would certainly be a useful first step, ultimately, we believe that a social licence for business model would require participation from a diverse array of stakeholders that goes beyond independent experts, to include representatives from groups such as local communities that the firm operates in, interest groups, employees, and other stakeholders.

One way to ensure workers are sufficiently heard and represented at the corporate decision-making level would be to adopt co-determination systems such as the German works councils. The German works council consists of worker representatives and must be involved in some major corporate decisions. For example, these topics include regulations regarding working hours and breaks, holiday, overtime and Kurzarbeit (a scheme whereby employees accept reduced working hours and pay, with the state making up for part of the lost wages, to avoid layoffs during economically difficult times), and introduction and usage of surveillance technology. They also include decisions about hiring and layoffs. Participation here means that the agreement of the works council is needed for decisions to take effect. Furthermore, the works council has to be informed about corporate decisions regarding rationalisation measures, shutdown, or expansion, and involved in decisions about the consequences of these decisions. Furthermore, the works council monitors compliance with laws and labour agreements and acts as a contact point for employees. ${ }^{38}$

\section{Creation/adaptation of monitoring bodies}

The third measure (touched on many times above) would involve identifying and building institutions ${ }^{39}$ to mediate and adjudicate. In order to deal with disputes around corporate governance, institutions would need to be identified or designed that offer mediation and adjudication, and that have powers to solve disputes. Examples for institutions that offer services along these lines include the Workplace Relations Commission and the Labour Court in Ireland, and the Enterprise Chamber in the Netherlands (Kavanagh \& Veldman 2020). For example, the main function of the Irish Workplace Relations Commission is to promote the improvement of workplace relations. It conducts reviews of workplace relations, provides guidance in relation to

\footnotetext{
${ }^{38}$ Information on works councils and workplace representation in Germany can be found in Fulton (2020).

${ }^{39}$ In connection with planned EU corporate due diligence legislation, European Commissioner for Justice, Didier Reynders, suggested a possible network of supervisory authorities at national level, coordinated at EU level (European Coalition for Corporate Justice 2020).
} 
compliance, and offers advice and information. It offers, for example, advisory, conciliation, and mediation services. Together with the Labour Court, which deals with all workplace relations appeals, the Workplace Relations Commission enforces employment rights.

Accountability mechanisms could be guided by existing criteria, such as those surrounding the National Contact Points for Responsible Business Conduct (NCPs for RBC). NCPs are governmental agencies which seek to embed the OECD Guidelines for Multinational Enterprises (the only multilaterally agreed and comprehensive code of responsible business conduct) and handle cases via a non-judicial grievance mechanism. To date, forty-nine governments have NCPs for RBC. The OECD Centre for Responsible Business Conduct suggests that criteria applicable to the NCPs for RBC could help guide accountability mechanisms to help monitor conditionality and resolve disputes (OECD 2020: 16-17).

\section{Benefits of, and challenges to, the social licence model}

Introduction of a social licence framework would be no small matter: what is needed is an alternative to standard regulation, something which can set aspirational rather than minimum standards, create a level playing field across firms, and has the power to discover, address, and seek redress where standards are not met, whilst also securing buy-in from companies, workers, and consumers and avoiding unnecessary and unhelpful bureaucracy. This is no easy set of conditions to meet, so careful research to assess the potential benefits and drawbacks of any new regulatory proposal would be needed. To close, in this section we offer a preliminary assessment of some of the potential benefits and drawbacks.

\section{Potential benefits of adopting a social licence model}

Evidence is emerging that companies that follow more narrowly defined ESG standards, on average, outperform the market (Hoffmann et al. 2020). As Morgan Stanley (2020) note, "The "social" decisions companies make today play no small role in their prospects tomorrow. Times of crisis can build greater loyalty, actually improve employee satisfaction and make or break a company's reputation in the marketplace.' (See also Edmans 2020.) There is thus, we suggest, a clear economic case (alongside the moral case considered here) for companies to adopt more ethical behaviour. Building on this, the social licence model offers a positive vision and unified framework to justify far-reaching systemic change. The social licence sets out a firm's social mission and targets. In doing so, it inspires better practice, putting human rights, ESG objectives, sustainability and future generations higher on the agenda and providing a 
platform for the measurement and enforcement of these aims and targets. These are elements of the creation of social value, which should be operationalised to provide a metric for reforms based on the social licence model.

The social licence (as conceived of here) is unique to individual businesses and can easily be adapted to changing circumstances, such as business growth, changing operations and supply chains, or the like. This flexibility is an advantage over standard regulation, which is not specific to individual firms and activities, and reflects the sense in which a good social licence system must constitute a partnership between company, state, and citizens. A social licence that is simply set and regulated from the centre will not be able to reflect the individual circumstances of firms, nor will it inspire the necessary confidence and agreement of the business community.

Finally, the social licence model inspires and encourages dialogue. It recommends forms of consensual decision-making with stakeholders and co-determination of employees. Such measures aim to change the conversation and to restore lost trust in business.

\section{Challenges to the social licence model}

A first challenge to the social licence model is that it may seem too costly for firms to implement: adopting the kind of reforms suggested by the social licence model (creation of a further board, additional or extended reporting requirements, and promoting social value creation alongside profit) may simply be something that companies cannot afford. The dual challenge of putting into practice far-reaching reforms based on the social licence model and recovering from the economic shock caused by the COVID-19 pandemic might become too much to shoulder.

However, as we have described above, there is a clear business case to be made for reforms. Businesses that score higher on ESG metrics outperform rivals and companies that fail to innovate (for example, in terms of 'greening' their products) risk being left behind by the market. Moreover, without fundamental reforms, economic recovery will lead us back to a business model that is simply unsustainable for people and planet, a model that people no longer trust. It does not seem too apocalyptic to suggest that the survival of the capitalist model itself may depend on the kind of changes discussed in this paper and reforms along the lines explored here actually constitute a return to a model of the relationship between society and business that underpinned the development of the corporation in the first place. Business itself is recognising the need to change, with individual companies and initiatives demanding reforms. If the UK embraces such reforms, this will support companies that are already looking for ways to do better and incentivise others to follow suit.

A second challenge to the social licence model is that it might appear too vague. Letting each company determine what compliance with the social licence looks like in 
its own case and what metrics it is to be judged by, and letting social licence boards have different compositions, seems to entail the loss of a level playing field, leading to problems with implementation, evaluation, and enforcement. The implementation of the social licence might be made more difficult by the lack of explicit requirements and comprehensive guidance. The evaluation and enforcement of measures might be difficult if they result in a patchwork of different measures being taken by individual companies, with no meaningful comparisons possible.

In response, we think it is important to note that, while standard regulation gives an appearance of certainty over the social licence model, regulations do not settle every situation a firm faces and often require careful consideration to apply to new cases (with the judgements of regulators and firms often coming apart, and with firms often facing significant legal costs in trying to determine what regulations require of them in practice). ${ }^{40}$ Furthermore, as argued above and elsewhere, it seems that standard regulation is fundamentally ill suited to do the work required, giving rise to loopholes/ unintended consequences and failing to set aspirational standards. If these worries with the role of standard regulation are well founded, then we have no choice but to explore an alternative form of regulation, one which looks to set principles rather than seeking to mandate specific behaviours. While it is true that ultimately a social licence model trusts that well-informed arbiters will make good judgements, both about setting social licence constraints in the first place and then assessing whether firms are meeting those targets, we suggest that the complexity of the ethical decisions firms face means that this is the only feasible approach.

In addition, we should note that greater certainty could be achieved through further development and implementation of the social licence model, including provision of guidelines, 'best practice' cases, and standard metrics for measuring progress in social value creation. ${ }^{41}$ Moreover, clear guidance and standards (perhaps sector-specific) might make it easier for businesses and stakeholders to compare performance. Here, a worry might arise, namely that, contrary to its mission, the social licence might become a tick-box exercise for firms, creating mere bureaucratic rather than real-world change. We acknowledge that there is no guarantee that the measures that we have proposed - most importantly a clear and unified framing of reforms, but also measures such as stakeholder dialogue, stringent reporting

\footnotetext{
${ }^{40}$ This is a point made in Luetge et al. (2016: 694), who note that 'The legal framework can never be refined enough to cover all possible situations and outcomes as it leaves corporations with not just one, but a number of possibilities to pursue their own interest.' Interestingly, they continue 'Institutions should be built that encourage ethical behavior, and to invest in such institutions is in the interest of companies, whether they already know it or not.'

${ }^{41}$ Proposals for such metrics are brought forward in a whitepaper by the World Economic Forum (2020). Moreover, metrics can also draw upon other established rankings, such as the Fair Tax Mark.
} 
requirements, and monitoring institutions - will achieve a fundamental shift in mindset. However, we suggest that the social licence model appears to be one of the most promising approaches currently on the table for bringing about such change.

\section{Conclusion}

In this paper, we have described a different way in which governments could leverage the influence gained by providing extensive support during the COVID-19 crisis to bring about necessary reforms in the private sector. We have argued that providing support without any conditions promotes a return to business as usual, when there are good reasons to think that serious change is needed. On the other hand, while welcome, extant regulatory conditions attached to support have several drawbacks and we have argued that these shortcomings cannot be addressed just by adopting more or better phrased standard regulation. Instead, then, we have suggested that the social licence for business model may provide a better framework for reform. Following the COVID19 crisis, which has thrown into stark relief the interdependency of the private sector, society, and the state, a change in the mindset across the private sector is needed. We have argued, in line with demands made by a broad array of politicians, business representatives, and interest groups, that what we need is to put the social purpose of companies to the fore. In addition to this, however, we have argued that living up to their social purpose is something society has the right to demand from businesses, due to the social contract in place between society and the private sector. Thus, if companies are to acquire and maintain their social licence to operate, we suggest that they need to give a concrete answer to the question of what social value they intend to contribute and how those intentions will be fulfilled. The social licence model provides, we suggest, a framework for a new understanding of the partnership between companies, the state, and the citizen, a framework which holds out the promise of harnessing the considerable power of the private sector to help society meet the challenges it faces.

\section{Acknowledgements}

For helpful feedback and discussion, thanks are due to Professors Brad Hooker and Philip Stratton-Lake, and the Directors and members of Ethical Reading. We are also grateful to an anonymous reviewer for this journal for very helpful comments and questions. This research was made possible by the award of a British Academy Special Research Award: COVID-19 scheme. 


\section{References}

Ashby, D. (2020, 27 August), 'Battered Russian Businesses Unable to Access Emergency COVID-19 Support Cite Overly Complex Rules', video, CNA. https://www.channelnewsasia.com/news/ business/battered-russian-businesses-unable-to-access-emergency-covid-19-13060214

Barmer, D., Kazi, D. \& Youel, S. (2020, July), 'The COVID Corporate Financing Facility. Where are the Conditions for the Billion $£$ Bailouts?', Positive Money. https://positivemoney.org/publications/ ccff/

Bebchuk, L.A. \& Tallarita, R. (2020), 'The Illusory Promise of Stakeholder Governance', Cornell Law Review, 106: 91-178. https://doi.org/10.2139/ssrn.3544978

Berry, C., Macfarlane, L. \& Nanda, S. (2020, May), 'Who Wins and Who Pays? Rentier Power and the Covid Crisis', The IPPR Centre for Economic Justice. https://www.ippr.org/files/2020-05/1589291707_who-wins-and-who-pays-may20.pdf

Borg, E. (2020), 'The Thesis of "Doux Commerce" and the Social Licence to Operate Framework', Business Ethics: A European Review, 1-11. https://doi.org/10.1111/beer.12279

British Academy (2019), Principles for Purposeful Business. https://www.thebritishacademy.ac.uk/ publications/future-of-the-corporation-principles-for-purposeful-business/

British Institute of International and Comparative Law, Civic Consulting, Directorate-General for Justice and Consumers (European Commission) \& LSE (2020, 20 February), Study on Due Diligence Requirements Through the Supply Chain, EU publications. https://op.europa.eu/en/ publication-detail/-/publication/8ba0a8fd-4c83-11ea-b8b7-01aa75ed71a1/language-en

Chapman, A. (2020, 27 April), 'Bailouts: Creating the New Normal', New Economics Foundation Blog. https://neweconomics.org/2020/04/bailouts-the-new-normal

Climate Action Network Europe (2020, June), 'The EU's Recovery Plan: Next Steps to Deliver on the European Green Deal', briefing paper. http://www.caneurope.org/publications/reports-andbriefings/1947-the-eu-s-recovery-plan-next-steps-to-deliver-on-the-european-green-deal

Corfe, S. (2020, 14 April), 'Intergenerational Fairness in the Coronavirus Economy', Social Market Foundation. https://www.smf.co.uk/publications/intergenerational-fairness-coronavirus/

Costanzo, G. (2020, 19 June), 'Strings attached? Environmental Conditionalities and State Aid', Global Counsel. https://www.global-counsel.com/insights/blog/strings-attached-environmentalconditionalities-and-state-aid

Donaldson, R. (2020, 18 November), 'Buy Back Better: Corporates and Regulators Need to Learn the Lessons from this Crisis', Transparency International UK.

https://www.transparency.org.uk/covid-19-coronavirus-bailout-stock-share-buyback?src=ilaw

Edmans, A. (2020), Grow the Pie: How Great Companies Deliver Both Purpose and Profit (Cambridge, Cambridge University Press). https://doi.org/10.1017/9781108860093

ETUC (European Trade Union Confederation) (2020, July), 'Letter Sent on EU Institutions on EU Recovery Fund (July 2020 European Council)'. https://www.etuc.org/en/document/lettersent-eu-institutions-eu-recovery-fund-july-2020-european-council

European Coalition for Corporate Justice (2020, 30 April), 'Commissioner Reynders Announces EU Corporate Due Diligence Legislation'. https://corporatejustice.org/news/16806-commissionerreynders-announces-eu-corporate-due-diligence-legislation

Filipova, T., Stainforth, T., Bodin, E. \& Charveriat, C. (2020, 29 April), 'Intergenerational Solidarity: What It Is and Why It Matters for Europe's Recovery', Institute for European Environmental Policy. https://ieep.eu/news/intergenerational-solidarity-what-it-is-and-why-it-matters-for-europes-recovery

Fulton, L. (2020), 'National Industrial Relations, An Update', Labour Research Department and European Trade Union Institute (online publication). http://www.worker-participation.eu/National-Industrial-Relations 
Geoffrey, B.P., McIver, T., Bisch, A. \& Chesney, G. (2020, 28 August), 'COVID-19-Review of Statesponsored Help for European Companies', Debevoise Insights. https://www.debevoise.com/ insights/publications/2020/03/covid19-so-far-state-sponsored-help-for

Ghosh, I. \& Goldberg, S. (2020, 20 August), 'Covid-19: The Deathknell of ESG Investing or a New Beginning?', TheStreet.

https://www.thestreet.com/economonitor/financial-markets/covid-19-esg-new-beginning

Gye, H. (2020, 14 July), 'Labour Split Claims as Ed Miliband Calls on State to Take Shares in Bailed-out Airlines', INews.

https://inews.co.uk/news/politics/labour-split-claims-ed-miliband-green-policy-539356

High Pay Centre (2020, 18 March), 'Conditions Are Critical: Why Publicly-funded Bail-outs for Private Companies Must Include Social and Environmental Conditions'. http://highpaycentre.org/pubs/ conditions-are-critical-publicly-funded-bail-outs-for-private-companies

HM Revenue and Customs (2020, 12 November), 'Coronavirus Job Retention Scheme Statistics: October 2020'. https://www.gov.uk/government/publications/coronavirus-job-retention-scheme-statisticsoctober-2020/coronavirus-job-retention-scheme-statistics-october-2020

Hoffmann, B., Armangue i Jubert, T. \& Parrado, E. (2020, June), 'The Business Case for ESG Investing for Pension and Sovereign Wealth Funds', policy brief, Inter-American Development Bank. https://publications.iadb.org/publications/english/document/The-Business-Case-for-ESG-Investingfor-Pension-and-Sovereign-Wealth-Funds.pdf; https://doi.org/10.18235/0002455

Hutton, G. \& Keep, M. (2020, 25 August), 'Research Briefing: Coronavirus Business Support Schemes: Statistics', House of Commons Library. https://commonslibrary.parliament.uk/research-briefings/cbp-8938/

Institute for Innovation and Public Purpose (2020, June), 'A Green Economic Renewal after the COVID19 Crisis', UCL IIPP COVID-19 Briefing Papers 04. https://www.ucl.ac.uk/bartlett/publicpurpose/sites/public-purpose/files/04_-_a_green_economic_renewal_after_the_covid-19_crisis_1. pdf

Institute of Directors (2019), 'IoD Manifesto: Corporate Governance'. https://www.iod.com/Portals/0/ PDFs/Campaigns $\% 20$ and $\% 20$ Reports/Corporate $\% 20$ Governance/IoD $\% 20$ Manifesto $\% 20-\% 20$ Corporate $\% 20$ Governance.pdf

International Labour Organization (2020, 29 April), ILO Monitor: COVID-19 and the World of Work, 3rd edn. https://www.ilo.org/wcmsp5/groups/public/---dgreports/---dcomm/documents/briefingnote/wcms_743146.pdf

Johnston, A., Veldman, J., Eccles, R.G., et al. (2020, 30 June), 'Corporate Governance for Sustainability', SSRN. https://papers.ssrn.com/sol3/papers.cfm?abstract_id=3502101

Kavanagh, D. \& Veldman, J. (2020, 29 July), 'It's a Myth that Companies Must Put Shareholders FirstCoronavirus is a Chance to Make it Stop', The Conversation. https://theconversation.com/ its-a-myth-that-companies-must-put-shareholders-first-coronavirus-is-a-chance-to-make-it-stop129104

Kay, J. (2019), 'The Concept of the Corporation', Business History, 61: 1129-43. https://doi.org/10.1080/00076791.2018.1509956

Leggett, T. (2020, 19 March), 'Coronavirus: EasyJet Staff May No Longer Be Given Food on Shifts', BBC News. https://www.bbc.co.uk/news/business-51962981

Loorbach, D.D. Schoenmaker \& W. Schramade (2020), 'Finance in Transition: Principles for a Positive Finance Future', Rotterdam School of Management, Erasmus University, Rotterdam.

Luetge, C., Armbrüster, T. \& Müller, J. (2016), 'Order Ethics: Bridging the Gap Between Contractarianism and Business Ethics', Journal of Business Ethics, 136(4): 687-7. https://doi.org/10.1007/s10551-015-2977-6

Mayer, C. (2020, 7 January), 'It's Time to Redefine the Purpose of Business. Here's a Roadmap', World Economic Forum Annual Meeting. https://www.weforum.org/agenda/2020/01/its-time-for-a-radical-rethink-of-corporate-purpose/ 
Morgan Stanley (2020, 6 April), 'Why the Coronavirus Puts a New Lens on ESG Investing'. https://www.morganstanley.com/ideas/coronavirus-corporates-esg-investing

Morrison, J. (2014). The Social License: How to Keep Your Organisation Legitimate (London, Palgrave Macmillan).

Norman, J. (2011, December), 'Conservative Free Markets, and the Case for Real Capitalism', House of Commons.

OECD (2020, 16 April), 'COVID-19 and Responsible Business Conduct'. http://www.oecd.org/coronavirus/ policy-responses/covid-19-and-responsible-business-conduct-02150b06/

Office for National Statistics (2020, 25 September), 'Public Sector Finances, UK: August 2020. How the Relationship Between UK Public Sector Monthly Income and Expenditure Leads to Changes in Deficit and Debt'. https://www.ons.gov.uk/economy/governmentpublicsectorandtaxes/public sectorfinance/bulletins/publicsectorfinances/august2020

O’Neill, O. (2014), 'Trust, Trustworthiness, and Accountability', in N. Morris \& D. Vines (eds) Capital Failure: Rebuilding Trust in Financial Services (Oxford, Oxford University Press), 172-92. https://doi.org/10.1093/acprof:oso/9780198712220.003.0008

Rouch, D. (2020), The Social Licence for Financial Markets (London, Palgrave Macmillan). https://doi.org/10.1007/978-3-030-40220-4

Scanlon, T. (1998), What We Owe to Each Other (Cambridge, MA, Harvard University Press).

Scanlon, T.M. (2003), The Difficulty of Tolerance: Essays in Political Philosophy (Cambridge, Cambridge University Press), ProQuest Ebook Central, https://ebookcentral.proquest.com/lib/reading/detail.action?docID=218199

Schoenmaker, D. \& Schramade, W. (2019), Principles of Sustainable Finance (Oxford, Oxford University Press).

Schwab, K. (2019, 1 December), 'Why We Need the “Davos Manifesto” for a Better Kind of Capitalism'. https://www.weforum.org/agenda/2019/12/why-we-need-the-davos-manifesto-for-better-kind-ofcapitalism/

Smoke, B.C. (2020, 4 August), 'Corporations Receiving Bailout Billions Have Laid off Staff and Paid Investors',VICE.https://www.vice.com/en/article/m7jxvn/corporations-receiving-bailout-billionshave-laid-off-staff-and-paid-investors

Strine, L. (2015), 'The Dangers of Denial: The Need for a Clear-eyed Understanding of the Power and Accountability Structure Established by the Delaware General Corporation Law', University of Pennsylvania Institute for Law and Economic Research Paper No. 15-08.

Taxwatch (n.d.), 'Paying in Equally?'. https://www.taxwatchuk.org/paying_in_equally/

Tett, G. (2020, 18 May), 'Business Faces Stern Test on ESG Amid Calls to "Build Back Better". Response to Pandemic Shows up Saints and Sinners-And Some Fuzziness on the Right Course of Action', Financial Times. https://www.ft.com/content/e97803b6-8eb4-11ea-af59-5283fc4c0cb0

Trades Union Congress (2020, 20 May), 'A Better Recovery. Learning the Lessons of the Corona Crisis to Create a Stronger, Fairer Economy'. https://www.tuc.org.uk/ABetterRecovery

UK Corporate Governance Code (July 2018), Financial Reporting Council. https://www.frc.org.uk/get attachment/88bd8c45-50ea-4841-95b0-d2f4f48069a2/2018-UK-Corporate-Governance-CodeFINAL.pdf

World Economic Forum (2020, January), 'Toward Common Metrics and Consistent Reporting of Sustainable Value Creation'. https://www.weforum.org/whitepapers/toward-common-metricsand-consistent-reporting-of-sustainable-value-creation 
To cite the article: Emma Borg and Charlotte Unruh (2021), 'Reshaping relations between the state and the private sector post-COVID-19? Exploring the social licence framework', Journal of the British Academy, 9: 87-113. DOI https://doi.org/10.5871/jba/009.087

Journal of the British Academy (ISSN 2052-7217) is published by The British Academy, 10-11 Carlton House Terrace, London, SW1Y 5AH www.thebritishacademy.ac.uk 
